\title{
Effect of refrigeration of resin materials on the occurrence of microleakage in class II restorations
}

\author{
Efeito da refrigeração dos materiais resinosos na ocorrência de microinfiltração em \\ restaurações classe II
}

\section{André Luiz Fraga BRISO}

PhD Assistant Professor of the Discipline of Restorative Dentistry at Araçatuba Dental School - UNESP - São Paulo State University - Araçatuba - SP - Brazil

\section{Renato Herman SUNDEFELD}

Associate Professor of the Discipline of Restorative Dentistry at Araçatuba Dental School - UNESP - São Paulo State University - Araçatuba - SP - Brazil

\section{Rebeca Lima AFONSO}

PhD student at Pediatric Dentistry at Araçatuba Dental School - UNESP - São Paulo State University - Araçatuba - SP Brazil

\section{Flavia Aparecida PATERNO}

Undergraduate student at Araçatuba Dental School - UNESP - São Paulo State University - Araçatuba - SP - Brazil

\section{Maria Lúcia Marçal Mazza SUNDEFELD}

PhD Assistant Professor of the Discipline of Biostatistics at Araçatuba Dental School - UNESP - São Paulo State University - Araçatuba - SP - Brazil

\begin{abstract}
Many professionals currently store their restorative materials in refrigerators, even though the manufacturers do not recommend this. This study evaluated the microleakage occurring in Class II restorations performed with composite resin stored at different conditions and temperatures. Thirty intact human molars were employed, which received vertical slot cavity preparations with the following dimensions: $3 \mathrm{~mm}$ in buccolingual direction, $1.5 \mathrm{~mm}$ in mesiodistal direction, and $5 \mathrm{~mm}$ in cervico-occlusal direction (at $1 \mathrm{~mm}$ short of the cemento-enamel junction). Specimens were restored with the adhesive material Prime \& Bond NT and composite resin TPH Spectrum (Dentsply) with 3 different conditions: G-I application of restorative materials at room temperature (nearly $25^{\circ} \mathrm{C}$ ), G-II application of restorative materials 30 minutes after removal from the refrigerator $\left(25^{\circ} \mathrm{C}\right)$, and G-III application of restorative materials immediately after removal from the refrigerator $\left(6^{\circ} \mathrm{C}\right)$. The specimens were sealed and immersed in $2 \%$ buffered methylene blue aqueous solution at $37^{\circ} \mathrm{C}$, for 4 hours. Thereafter, the specimens were sectioned and evaluated as to the degree of marginal leakage at the dentin-cementum/restoration interface and also as to the type of dye leakage observed. Data achieved were submitted to statistical analysis by the non-parametric method Kruskal-Wallis $(\mathrm{p}<0.05)$ for comparison of the degree of leakage, and ratio test for comparison of differences in the pattern of leakage. No adverse effects were observed on the occurrence and pattern of microleakage when the restorative system was employed immediately after or 30 minutes after storage in the refrigerator, or at room temperature.
\end{abstract}

\section{UNITERMS}

Microleakage, restorative materials, storage, adhesive systems. 


\section{INTRODUCTION}

Assigning the success of restorations only to the materials is a standpoint of a surgical-restorative dentistry, which is "materialist" and not much biological. It is known that the development of carious lesions, either primary or adjacent to restorations, depends on factors present in the oral environment that may lead to an imbalance in the health-disease state, as expressed by the demineralization-remineralization process $^{2,10}$.

However, restorations are required as they recover the function, occlusion, and in some cases esthetics. Thus, an ideal restorative material should present excellent characteristics as to wear, fractures, linear coefficient of thermal expansion similar to that of the tooth, surface smoothness, biocompatibility, and especially hermetic sealing of the tooth-restoration interface ${ }^{1,9}$. Thus, it is understood why achievement of a restorative material with the aforementioned characteristics is one of the main ambitions of restorative dentistry ${ }^{2,11}$.

Thus, when performing restorative procedures, professional often prefer to use adhesive resin materials, which are a conservative option and further restore the esthetics and function of the tooth to be restored.

It should be highlighted that achievement of effective adhesion of these materials to the dental tissue is fundamental to allow proper marginal sealing and longevity of the restorations.

Among the factors that determine the success of adhesion, temperature and humidity of the environment and materials play an important role and may lead to success or failure of the procedure ${ }^{8,14}$.

Within this context, even though most manufacturers recommend storage of the materials at room temperature, many professionals store their adhesive materials in the refrigerator, with a view to extend the expiry date of the product or even preserve some properties.

However, in some situations, materials are employed immediately after removal from the refrigerator, and are not allowed to reach the room temperature.

The literature informs that utilization of resin materials at low temperatures may lead to harmful effects in adhesion of materials ${ }^{8}$. Similarly, the alteration in viscosity of the adhesive system and possible influence of evaporation of the solvents present in these materials may impair their penetration into the dental tissue ${ }^{18}$. Moreover, reduction in temperature of composite resins may influence the degree of curing of the materials, impairing their physical properties and the longevity of restorations $\mathrm{s}^{3,5}$.

Thus, this study evaluated the microleakage occurring in Class II restorations performed with composite resin stored at different conditions and temperatures.

\section{Materials AND MEthods}

This study was conducted on 30 freshly extracted intact human molars. The teeth were extracted because of reasons not related to this study, and extractions were performed by the professionals of FUSC (Health Foundation of Cuiabá). Before get starting the study, the research protocol was submitted and evaluated by the Institutional Review Board to obtain an approval (p.2002/01711).

After collection of teeth, they were cleaned with periodontal curettes (Dental Duflex Ltda), followed by polishing with pumice and water, with aid of a brush (KG Sorensen Ind. e Com. Ltda) at low-speed. Then, the teeth were stored in $2 \%$ formalin solution with neutral $\mathrm{pH}$ at room temperature until utilization.

In order to standardize the cavity preparations, the occlusal surfaces were sectioned with a double-face flexible diamond disc (Ref. 7020 - KGSorensen), at low-speed handpiece (Dabi - Atlante). All teeth were ground until the occlusal surface was at $4 \mathrm{~mm}$ from the cementoenamel junction.

Class II vertical slot cavity preparations were performed with carbide burs (FG 245) perpendicular to the occlusal surface, under constant pressure, at high-speed with air-water cooling. Cavity preparations were thus extended in $3 \mathrm{~mm}$ in buccolingual direction, $1.5 \mathrm{~mm}$ in mesiodistal direction and $5 \mathrm{~mm}$ in cervicoocclusal direction, so as the cervical margin of the preparations was located $1 \mathrm{~mm}$ beyond the cementoenamel junction. It should be highlighted that each bur was employed for fabrication of 6 cavities, being then replaced. For standardization of the cavity preparations, the dimensions were continuously measured with a digital pachymeter.

After accomplishment of cavity preparation, the cavities were identified with a number placed apical to the preparations, followed by storage in identified flasks containing distilled water.

Then, the specimens received another prophylaxis, followed by washing and drying, for application of $35 \%$ phosphoric acid gel for 15 seconds. After this period, the specimen was thoroughly washed in tap 
water, gently air-dried keeping the dentin humid, and the adhesive material Prime \& Bond NT (Dentsply) was applied. A period of twenty seconds was allowed to check if the dental tissue still presented a humid aspect. Otherwise, the adhesive was reapplied, following the manufacturer's instructions. The adhesive was then light cured for 10 seconds.

Soon after, the composite resin TPH Spectrum (Dentsply) was placed by the incremental technique, with horizontal increments with a mean thickness of $1.7 \mathrm{~mm}$ and was light cured for 40 seconds.

As demonstrated in Chart 1, the specimens in G-I received application of adhesive materials (adhesive and composite resin) at room temperature, i.e. nearly $25^{\circ} \mathrm{C}$. The specimens in G-II were restored $30 \mathrm{mi}-$ nutes after removal of adhesive materials from the refrigerator $\left(25^{\circ} \mathrm{C}\right)$. Specimens in G-III were restored immediately after removal of the materials from the refrigerator, which kept a constant temperature of $6^{\circ} \mathrm{C}$ (Chart 1).

After accomplishment of the restorative procedures, the specimens were stored in a humidifying chamber (Soc Fabble Ltda) at $37^{\circ} \mathrm{C}$ for 7 days, followed by polishing with Soflex aluminum oxide discs (3M).

For ideal sealing of the areas outside the tooth/ restoration interface, as well as to standardize the amount of dental tissue to be exposed to the dye, 2 coats of nail enamel were applied on the tooth and restoration, except for $1 \mathrm{~mm}$ around the cervical margin of restorations. The cervical margins were protected from application of nail enamel by previous placement of adhesive tapes in these regions.
After drying of the nail enamel, the specimens were placed in identified flasks containing buffered $2 \%$ methylene blue aqueous solution at $37^{\circ} \mathrm{C}$, for 4 hours. After this period, the specimens were removed from the dye, washed in tap water for 2 minutes, and allowed to dry for 24 hours at room temperature.

Following, the teeth were sectioned through the center of restorations in mesiodistal direction. This led to achievement of two tooth fragments; one was employed for evaluation, and the other was discarded. The fragment to be evaluated was randomly selected during sectioning.

The sections were evaluated as to the degree of marginal dye leakage at the dentin-cementum/restoration interface, with a stereomicroscope Nova-Optical Systems, with $45 \mathrm{x}$ magnification. For evaluation of the degree of marginal dye leakage, previously established scores from 0 to 4 were employed for the dentinal tissue margins, as illustrated in Scheme 1 and described in Chart 2.

During analysis in the stereomicroscope, evaluation was also performed as to the type of dye leakage, i.e. sections were scored as "A" if there was no dye leakage, " $\mathrm{B}$ " if dye leakage was restricted to the adhesive/resin interface, and " $\mathrm{C}$ " if dye leakage extended to the dentin. Thus, it was possible to analyze where there was failure of adhesion, either between the hybrid layer/adhesive and resin or between hybrid layer/ adhesive and dentin (Charts 3 and Scheme 2).

Analysis of marginal leakage was conducted by 2 calibrated examiners; in case of discordant opinions, the specimen was reevaluated until consensus was reached.

Chart 1 - Study groups according to the storage and temperature of adhesive materials.

\begin{tabular}{c|l}
\hline Group & Storage \\
\hline I & Room temperature $(250 \mathrm{C})$ \\
\hline II & $\begin{array}{l}\text { Materials refrigerated at } 60 \mathrm{C} \text { and removed from the refrigerator } 30 \text { minutes before accomplishment of } \\
\text { restorations. }\end{array}$ \\
\hline III & Immediately after removal of materials from the refrigerator (nearly $60 \mathrm{C})$. \\
\hline
\end{tabular}




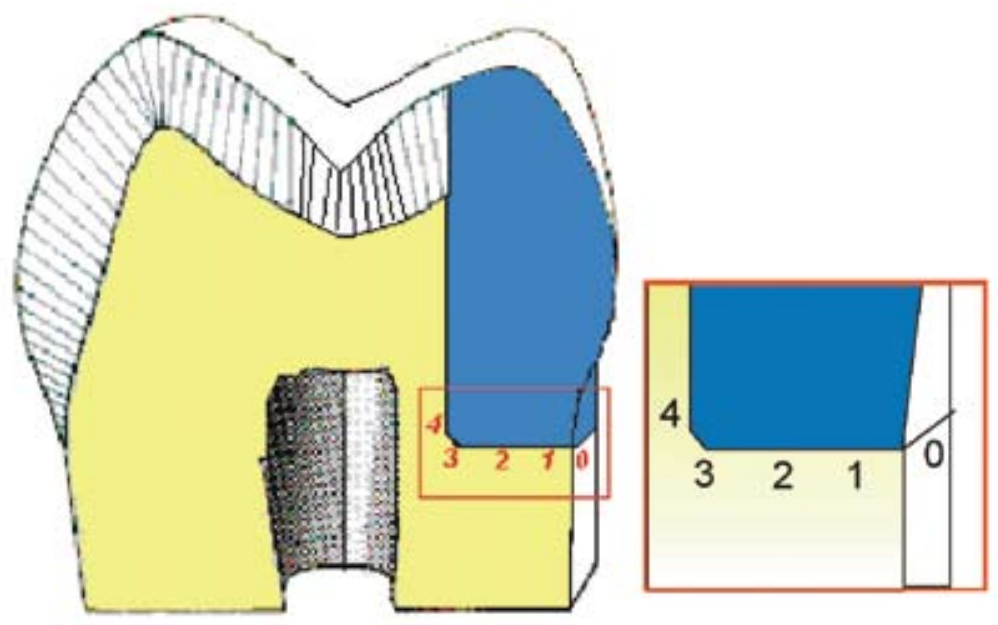

Scheme 1 - Scheme of scores adopted for evaluation of specimens

Chart 2 - Evaluation of the degree of marginal leakage at the cervical margin (dentin/cementum)

\begin{tabular}{c|c|l}
\hline Score & Degree & \multicolumn{1}{c}{ Marginal leakage } \\
\hline 0 & Absent & Absence of dye penetration at the dentin/restoration interface. \\
\hline 1 & Small & $\begin{array}{l}\text { Dye penetration at the dentin/restoration interface, up to the first third of the } \\
\text { distance between the cavity margin and axiocervical angle. }\end{array}$ \\
\hline 3 & Loderate & $\begin{array}{l}\text { Dye penetration at the dentin/restoration interface, up to the space between the first } \\
\text { and second thirds of the distance between the cavity margin and axiocervical angle. } \\
\text { Dye penetration at the dentin/restoration interface, up to the space between } \\
\text { the second and third thirds of the distance between the cavity margin and } \\
\text { axiocervical angle. }\end{array}$ \\
\hline 4 & Severe & $\begin{array}{l}\text { Dye penetration at the dentin/restoration interface, reaching or surpassing the } \\
\text { axiocervical angle. }\end{array}$ \\
\hline
\end{tabular}

Chart 3 - Pattern of marginal leakage according to the interface affected by the dye.

\begin{tabular}{c|l}
\hline Score & Interface with dye leakage \\
\hline A & Specimen with no dye leakage. \\
\hline B & $\begin{array}{l}\text { Specimen with dye leakage through the adhesive/composite resin interface, with no penetration } \\
\text { into dentinal tissue. }\end{array}$ \\
\hline C & $\begin{array}{l}\text { Specimen with dye leakage through the adhesive system/dentin interface, invading the dentinal } \\
\text { tissue. }\end{array}$ \\
\hline
\end{tabular}




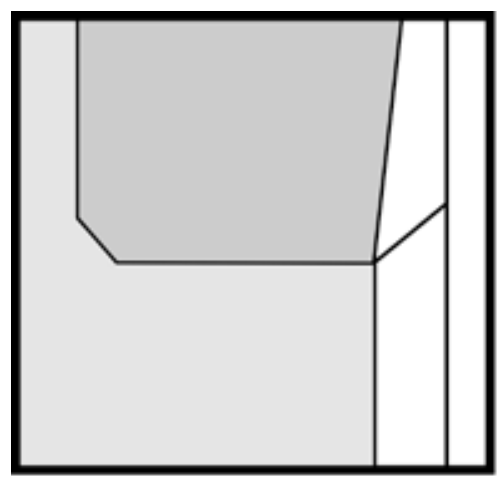

Escore A

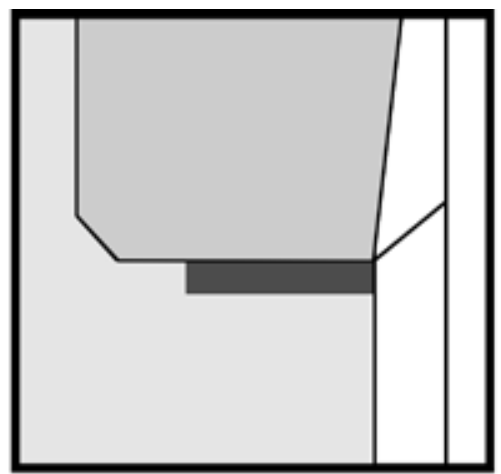

Escore B

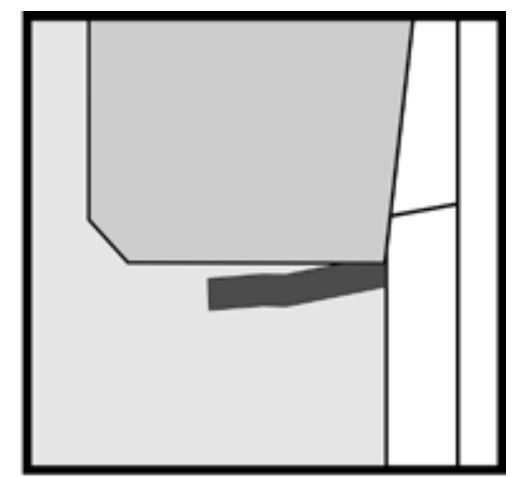

Escore C

Scheme 2 - Pattern of dye leakage

The results of the microleakage test were tabulated and submitted to statistical analysis, by utilization of the non-parametric Kruskal-Wallis test at the 5\% level. Analysis of the pattern of leakage was performed by the ratio test, for comparison of the occurrence of patterns "A", "B" and "C" for each study group.

\section{Results}

Tables 1 and 2 demonstrate the result of the Kruskal-Wallis test for evaluation of marginal leakage and ratio test for comparison of the degree of microleakage between groups. This revealed that there was no difference between the study groups, i.e. the storage conditions and utilization of adhesive restorative materials did not influence the occurrence and pattern of microleakage in the restorations. The figures 1,2 and 3 illustrate the degree and pattern of marginal leakage.

\section{Discussion}

The influence of temperature and humidity on the adhesion of resin materials to the tooth substrate has been addressed in some studies, especially related to bond strength ${ }^{4,6,16}$ and more recently to formation of enamel tags ${ }^{17}$. This led to complementation of this knowledge by investigation of the occurrence of marginal leakage in restorations performed with resin materials stored at different conditions.

Most professionals usually store the restorative materials in refrigerators at low temperatures. However, it is known that removal of these materials from the refrigerator leads to an increase in humidity of these materials, which is a matter of concern as to the achievement of proper adhesion to the tooth substrate, as well as marginal sealing to assure longevity of restorations.

It should be considered that achievement of ideal conditions of humidity is a matter of concern for several clinicians, investigators and even manufacturers of adhesive systems, since after etching of the dentinal substrate with phosphoric acid gel, there is exposure of collagen fibers without dentinal support and penetration of hydrophilic components of the adhesive system into this mesh of collagen fibers, leading to formation of the hybrid layer ${ }^{12}$. Currently, there is consensus among investigators that this structure accounts for a great part of the adhesion of adhesive materials to the dentinal tissue ${ }^{7,12}$. Thus, if the substrate is too dry, there will be collapse of the collagen fibers, impairing the penetration of hydrophilic monomers, leading to improper formation of hybrid layer ${ }^{7,12,13}$. On the other hand, deficient drying of the etched dentinal substrate, i.e. presence of excess water on the dentin impairs interaction of the bonding agent with the demineralized dentin, favors the appearance of air or water bubbles in the hybrid layer and adhesive layer, due to improper evaporation of water and/or solvent ${ }^{18}$, leading to low bond strength values $7,12,13,18$.

The results of the present study revealed that marginal sealing was not affected by the different conditions at which the materials were applied, i.e. the temperature of the restorative system investigated did not influence the level of marginal leakage in Class II restorations. Similarly, when there is marginal leakage, presence of the dye penetrating into dentinal tissue or restricted to the adhesive system/composite resin interface was not altered by the experimental conditions investigated. These data may be explained 
Table 1 - Result of the Kruskal-Wallis test as to the occurrence of microleakage.

\begin{tabular}{c|c|c}
\hline \multicolumn{3}{|c}{ Kruskal Wallis Test } \\
\hline Groups & $\mathbf{n}$ & Mean of ranks \\
\hline GI & 20 & 33.53 \\
\hline GII & 20 & 28.38 \\
\hline GIII & 20 & 29.60 \\
\hline total & 60 & \\
* Non significant at $5 \% \mathrm{x}^{2}=1.011$ & p value $=0.603$
\end{tabular}

Table 2 - Comparison of the pattern of marginal leakage by the ratio test.

\begin{tabular}{c|c|c|c|c}
\hline \multicolumn{5}{c}{ Ratio test } \\
\hline Pattern & GI & GII & GIII & p value \\
\hline A & 0.25 & 0.5 & 0.25 & 0.1534 \\
\hline B & 0.45 & 0.25 & 0.35 & 0.4141 \\
\hline C & 0.3 & 0.25 & 0.4 & 0.5832 \\
\hline p value & 0.3772 & 0.1554 & 0.5916 & \\
\hline
\end{tabular}

* No comparison was significant at the $5 \%$ level.

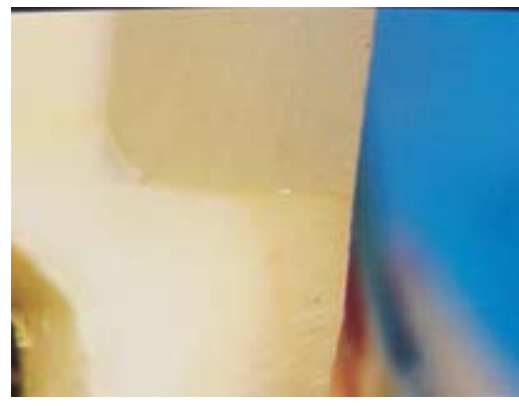

Figure 01 - Specimen with absent dye leakage at the dentin/restoration interface (Score 0-A) - 45x.

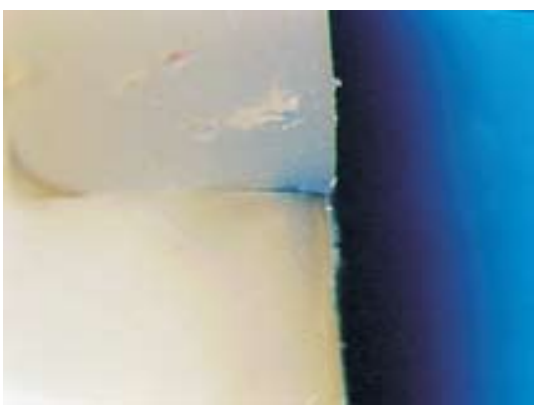

Figure 02 - Specimen with small dye leakage at the dentin/restoration interface (Score 1-B) - 45x.

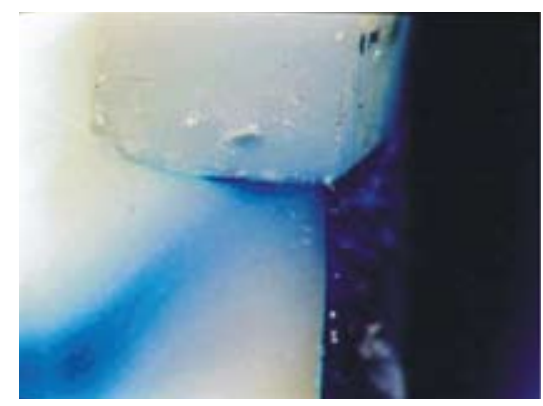

Figure 03 - Specimen with large dye leakage at the dentin/restoration interface (Score 3-C) - 45x. by the fact that the adhesive system Prime \& Bond NT (Dentsply), which has acetone as its main solvent, did not suffer alterations by evaporation of this component, in agreement with Spohr et al. ${ }^{16}$ (2001). Thus, it may be assumed that refrigeration of the adhesive material did not impair evaporation of acetone, which is an important and necessary factor for achievement of good interaction between the adhesive material and dentinal tissue.

On the other hand, Sundfeld, et al. ${ }^{17}$ (2005) observed a significant reduction in the length of tags formed in dental enamel receiving an intermediate adhesive agent immediately after removal from the refrigerator; however, in that study, the substrate investigated was the dental enamel, whose histological characteristics are different than those of the dentinal tissue, which was addressed in this study. Moreover, these authors employed a self-etching adhesive system; therefore, the steps of etching, washing and drying were not performed and thus were not influenced by the operator. The present study attempted to achieve an ideal pattern of dentinal etching and humidity for application of the hydrophilic adhesive system.

Spohr et al. ${ }^{16}$ (2001) compared the bond strength achieved with the system Prime \&Bond NT applied at different temperature and storage conditions and also did not find any statistically significant difference between the study groups, which may confirm the present hypothesis that achievement of conditions of an ideal substrate is more important than the conditions of storage and utilization of this material.

Thus, the present study agrees with the findings of Tay et al. ${ }^{18}$ (1995) which demonstrated that achievement of an ideal pattern of humidity of the dentinal substrate is fundamental for interaction of the adhesive material and the tooth structure previously etched by $35 \%$ phosphoric acid, this condition was reached by protection of dentin with absorbent paper placed inside the cavity preparations before drying and application of the adhesive system. Therefore, it was possible to obtain dental enamel with well-dried, opaque and porous aspect, whereas the dentin kept its peculiar humid aspect.

All these data demonstrate the importance of care of the operator when applying the adhesive systems, always attempting to work with placement of rubber dam and following the manufacturer's instructions, which usually advocate application of adhesive systems with hydrophilic monomers on humid dentin. 


\section{Conclusions}

No adverse effect was observed in the occurrence and pattern of microleakage at the dentin-cementum/ restoration interface in Class II cavities, when the adhesive and restorative systems were employed immediately after storage in the refrigerator, as well as after 30 minutes or at room temperature.

\section{Resumo}

Atualmente muitos profissionais armazenam seus materiais restauradores em refrigeradores, mesmo o fabricante não determinando que esta condição seja obedecida. Assim, este trabalho avaliou a microinfiltração ocorrida em restaurações classe II de resina composta armazenada em diferentes condições e temperaturas. Foram empregados 30 molares humanos hígidos que receberam preparos cavitários, tipo "slot" vertical, com dimensões: $3 \mathrm{~mm}$ no sentido vestíbulolingual, 1,5 $\mathrm{mm}$ no sentido mésio-distal e $5 \mathrm{~mm}$ no sentido gêngivo-oclusal ( $1 \mathrm{~mm}$ abaixo do limite amelo-cementário). Os espécimes foram restaurados com o material adesivo Prime \& Bond NT e resina composta TPH Spectrum (Dentsply) em 3 diferentes condições: G-I aplicação dos materiais restauradores na temperatura ambiente (aproximadamente $25^{\circ} \mathrm{C}$ ), G-II aplicação dos materiais restauradores 30 minutos após suas remoções do refrigerador $\left(25^{\circ} \mathrm{C}\right)$, e G-III aplicação dos materiais restauradores imediatamente após a retirada do refrigerador $\left(6^{\circ} \mathrm{C}\right)$. Os espécimes foram vedados e imersos em solução aquosa de azul de metileno, tamponado, a $2 \%$, na temperatura de $37^{\circ} \mathrm{C}$, por 4 horas. Em seguida, foram cortados e avaliados quanto ao grau de infiltração marginal na interface dentina-cemento/restauração e também quanto ao tipo de penetração que o corante apresentou. Os dados obtidos foram submetidos à análise estatística, empregando o método não paramétrico de Kruskal-Wallis $(\mathrm{p}<0,05)$ para comparar o grau de infiltração e o teste de proporção para comparar diferenças no padrão de infiltração. Não foi observado efeito adverso na ocorrência e no padrão de microinfiltração quando o sistema restaurador foi empregado imediatamente após sua armazenagem em refrigerador, bem como 30 minutos após ou em temperatura ambiente.

\section{UNITERMOS}

Microinfiltração; materiais restauradores, armazenamento; sistema adesivo.

\section{REFERENCES}

1. Alani AH, Toh CG. Detection of microleakage around dental restorations: a review. Oper Dent. 1997 jul./aug.;22(4):173-85.

2. Baratieri LN, Caldeira de Andrada MA, Monteiro S Jr. Dentística restauradora: fundamentos e possibilidades. São Paulo: Santos; 2001.

3. Bausch JR, de Lange C, Davidson CL. The influence of temperature on some physical properties of dental composites. J Oral Rehabil 1981 jun.;8(4):309-17.

4. Bishara SE, Thunyaudom T, Chan D. The effect of temperature change of composites on bonding strength of orthodontic brackets. Am J Orthod Dentofacial Orthop 1998 nov.;94(5):440-1.

5. Briso ALF. Avaliação da infiltração marginal e microdureza em restaurações classe II realizadas com diferentes sistemas restauradores e técnicas de inserção. [Tese de Doutorado]. Piracicaba: Faculdade de Odontologia de Piracicaba, Universidade Estadual de Campinas; 2001.

6. Burrow MF, Taniguchi Y, Nikaido T, Satoh M, Inai N, Tagami J, et al. Influence of temperature and relative humidity on early bond strengths to dentine. J Dent 1995 feb.;23(1):41-5.

7. Gwinnett AJ, Kanca JA 3rd Micromorphology of the bonded dentin interface and its relationship to bond strength. Am J Dent 1992 apr.;5(2):73-7.

8. Hagge MS, Lindemuth JS, Broome JC, Fox MJ. Effect of refrigeration on shear bond strength of three dentin bonding systems. Am J Dent 1999 jun.;12(3):131-3

9. Kidd EA. Microleakage: a review. J Dent 1976 sep.;4(5):199-206.

10. Kriger L. ABOPREV: Promoção de saúde bucal. São Paulo: Artes Médicas; 1997

11. Maltz M, Carvalho J. Tratamento da doença cárie. In: Krieger, L. ABOPREV. Promoção de saúde bucal. São Paulo: Artes Médicas; 1997. p.69-91.
12. Nakabayashi N. Bonding of restorative materials to dentine: the present status in Japan. Int Dent J 1985 jun.;35(2):145-54.

13. Nakaoki Y, Nikaido T, Burrow MF, Tagami J. Effect of residual water on dentin bond strength and hybridization of a one-bottle adhesive system. Oper Dent 2002 nov./dec.;27(6): 563-8.

14. Nystrom GP, Holtan JR, Phelps RA 2nd, Becker WS, Anderson TB. Temperature and humidity effects on bond strength of a dentinal adhesive. Oper Dent 1998 mar./apr.;23(3):138-43.

15. Rossomando KJ, Wendt SL Jr. Thermocycling and dwell times in microleakage evaluation for bonded restorations. Dent Mater 1995 jan;11(1):47-51.

16. Spohr AM, Correr Sobrinho L, Consani S, Sinhoreti MA, Borges GA. Effect of refrigeration on tensile bond strength of three adhesive systems. Braz Dent J 2001; 12(2):75-9.

17. Sundfeld RH, Silva AMJD, Croll TP, Oliveira CH, Briso ALF, Sundefeld MLMM. The influence of temperature on penetration (tags) of a self-etching adhesive into ground and unground enamel. Journal Adhesive of Dentistry (enviado e em análise - 2005).

18. Tay FR, Gwinnet AJ, Pang KM, Wei SHW. Variability in microleakage observed in a total-etch wet-bonding technique under different handling conditions. J Dent Res 1995 may;74(5):1168-78.

Recebido em 18/10/2005 Aprovado em 13/09/2007

Correspondence to: Prof. Dr. André Luiz Fraga Briso UNESP - FOA Rua José Bonifácio 1193, 16015-050 - Araçatuba - SP - Brazil. e-mail: alfbriso@foa.unesp.br 